\title{
Establishment of Contract Management System for Construction Company \& Subcontractor
}

\author{
Yan-Chyuan Shiau, Cheng-Wei Liu, Shu-Jen Sung, Chih-Kun Chu and Tsung-Pin Tsai
}

\begin{abstract}
The Construction environment has been changed tremendously for last few years in Taiwan. Since the capital has been flowed to China, real estate has no more good market. By the way, the practice of volume ratio makes the problem of vacant houses worse. In order to solve the land investment pressure, build companies need to raise the new project even though the market is always very bad. Since the profit is quite limited, construction companies will face the problem that the management capability will dominate the survival of the company.

In order to survive in the competitive environment, Construction Company needs to handle every stage such as bidding, purchasing, and construction. This situation can prove that the construction management is a necessary tool for current environment. A good contracting system is a must tool to make the forever operation be possible for construction company.

In a construction project, a fair and good contract is to protect both Construction Company and subcontractors. Since most construction company has limited human power and resources, a completed Contract Management System is really a good help for middle/small size construction companies. In this research, we have developed a well-considered and fair specification that will state the responsibilities and rights for both sides. This is an important tool to assure the completion of a construction project.
\end{abstract}

Index Terms-Contract Administrating, Construction Specification, Construction Industry, Purchasing.

\section{ORIGINS \& OBJECTIVES}

$\mathrm{T}$ he construction industry has faced impact of economic depression and this has caused dramatic drop of profits. In order to survive in such environment, improvement on management skills, integration of modern hardware / software is expected to combine with construction information, which reduces loss due to bad management. For effective regulation on responsibility and duty between construction company and

This work was supported in part by the National Science Council, Executive Yuan, Taiwan under Grant NSC 92-2622-E-216-021-CC3.

Yan-Chyuan Shiau is with the Department of Construction Engineering, Chung-Hua University, Hsin-Chu, 300 Taiwan (Tel: 886-3-5186689; Fax: 886-3-5378846; E-mail: ycshiau@ms22.hinet.net).

Cheng-Wei Liu is the graduate student of the Institute of Construction Management, Chung-Hua University, Hsin-Chu, 300 Taiwan (E-mail: teran1118@yahoo.com.tw)

Shu-Jen Sung is with Kang \& Associates, Ju-Bei, Hsin-Chu, 302 Taiwan (Email:tifa147@ms24.hinet.net).

Chih-Kun Chu is with the Excellent Instrument \& Engineering Co. Ltd., Tu-Chen, Taipei, 236 Taiwan (E-mail: jack@excellent.com.tw)

Tsung-Pin Tsai is with the Construction Section, Chu-Nan Town Hall, Miao-Li, Taiwan (E-mail: winnie.bears@msa.hinet.net) sub-contractor, a fair and effective contract management system is work not to be avoided for current construction industry to improve its competitiveness and establish profit. This research will combine the systems of "object-orientation, visual simulation, using PDA (Personal Digital Assistant), to build a search function on construction site regulations, quality inspection and project records", which allows construction companies to put site management into further practice. This will further help the construction company in effective contract management with subcontractors, properly put the contract management into practice, which prevents possible conflicts in the future, improves ability of management in construction industry, saves unnecessary waste, improves quality in the industry and develops profits.

To insert images in Word, position the cursor at the insertion point and either use Insert | Picture | From File or copy the image to the Windows clipboard and then Edit | Paste Special | Picture (with "Float over text” unchecked).

\section{Functional Requirements}

The main function of this system was to help construction company in setting of subcontractor agreements. When user clicked on project items to be contracted and entered information of relevant work, the system could then automatically produce a copy of construction contract, which precisely listed relevant things to note for contracting of each project within an edited structure. These relevant documents included:

1) Construction contract.

2) Construction drawings.

3) Shop drawings made by contractor and approved by construction company or the site manager.

4) Construction description.

5) Things to note for construction project.

6) Construction quotation.

7) Notification of project commencement.

8) Agreement for project security and health.

9) Guarantee of construction contract.

10) Worker's insurance agreement.

11) Stamp card for company's payment receipt.

12) Record of construction project.

13) Registration card of construction project.

14) Supplementary description.

15) Amendment of contract. 
16) Registration of company.

17) Application form for business tax.

\section{DiscusSiOn OF DATABASE STRUCTURE}

\section{A. Analysis of Database Structure}

Structure of database was the core of the system; once mistakes occurred in it or user's requirement was not complied with, the whole information flow would be incorrect and output unexpected information. Therefore, drafting a structure of database that complies with functional requirements of the system was the key to success of the project.

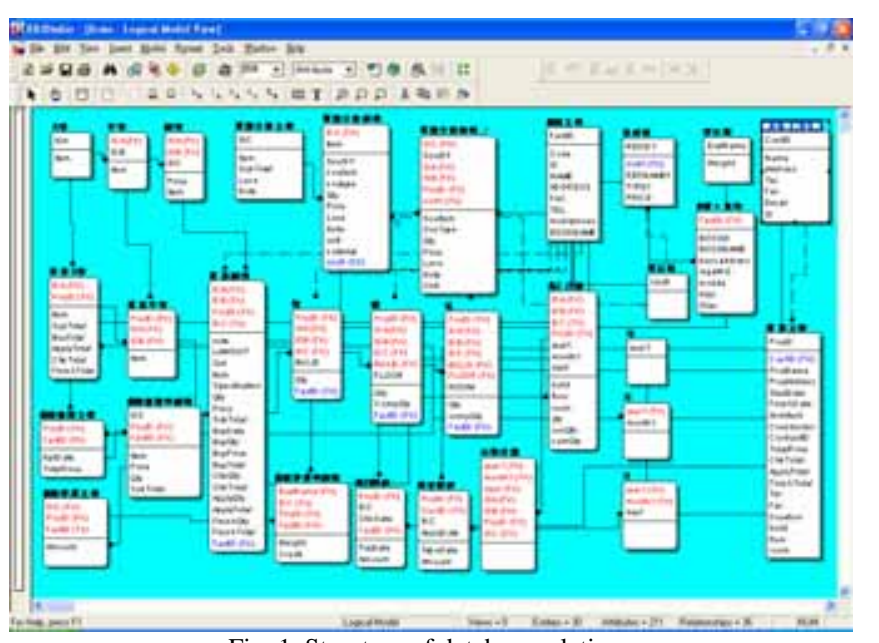

Fig. 1 Structure of database relations

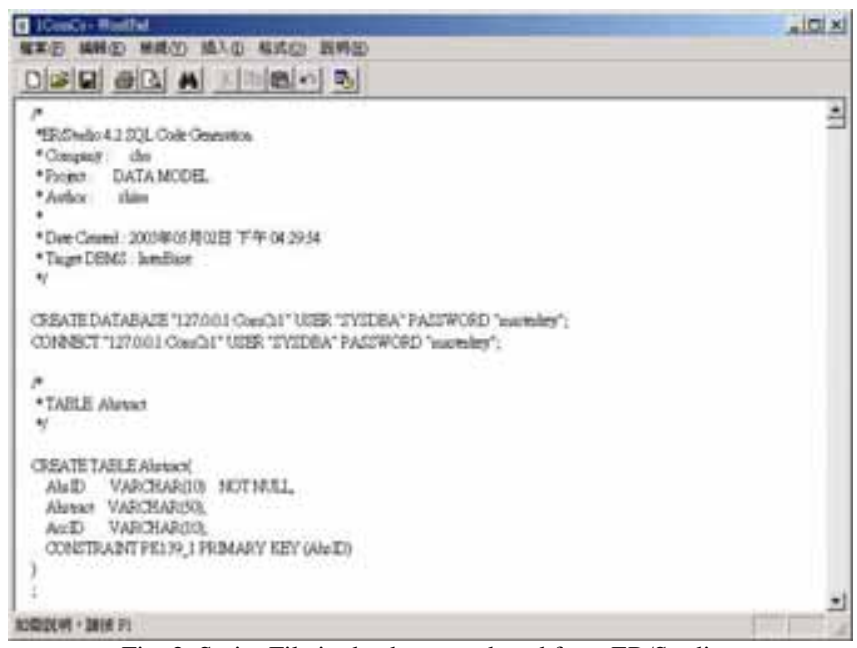

Fig. 2 Script File in database produced from ER/Studio

Along with advancing information technology, the database system has developed from the traditional "Relational Database” to "Object-Oriented Database" (OODB). The OODB has become the mainstream of development on database management systems. This research used the ER/Studio tool to build an ER Diagram, and then follows this model to plot the information procedure according to user's requirements and build an E-R Model (Entity-Relationship Model). After definition of interactive relationships between columns and tables of each information sheet, the actual database is built, i.e. the database of actual relationships (as shown in Fig. 1).

After building the ER/Model, user may use tools provided by the software to transform the structure of database into Script File (as shown in Fig. 2) readable by normal database management system. The Database Console is allowed to read data sheet of system, columns in each data sheet, property of each column, as well as relationship between Primary Key and Foreign Key of each information sheet to build the database of system.

\section{B. Content of Contract Guarantee}

The contract guarantee (as shown in Fig. 3) is normally issued by guarantor company to the construction company as guarantee of contract performance. When contractor could not perform the obligation, complete in time or had to be responsible for indemnification due to contractor's fault that induced accident, the guarantor company must take joint responsibility. The content includes:

1) Name of project.

2) Location of project.

3) Contracting items.

4) Name of guarantor.

5) Name of contractor.

6) Items guaranteed, which normally contained:

a. Guarantee on performing any duty and responsibility of the contract on contractor's behalf.

b. If there was any duty occurred from canceling of contract due to certain cause, joint responsibility must be taken.

c. If the contractor entered into agreement with construction company on extension of project deadline, or there is change of content and addition / reduction to amount of project, the guarantor must continue with the guarantee.

d. The liable period of guarantee is counted since the date of signing contract for mutual guarantee till expiration of guarantee period; no withdrawal of guarantee is allowed halfway without written consent.

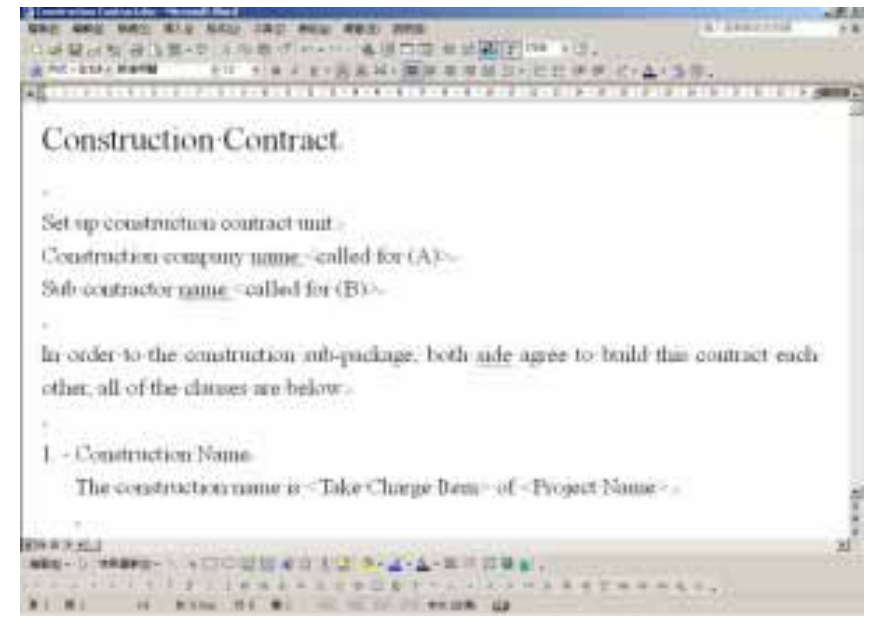

Fig. 3 Content of contract guarantee 
7) Relevant information of person entering into guarantee, which includes name of company, GUI number, address, telephone, name of contact person and identity number.

8) Date of guarantee establishment.

\section{Content of Worker's Insurance Agreement}

The content of worker's insurance agreement is mainly proved by the contractor in writing, which agrees that contractor must take relevant labor, health and accident insurance for the workers to ensure a certain degree of protection when accident occurs:

1) Name of project.

2) Location of project.

3) Items contracted.

4) Items guaranteed, which normally include the following:

a. Labor, accident and other relevant insurance have been taken out for all personnel employed by the contractor during construction period.

b. If any accidental disaster occurs to personnel employed by the contractor on site, such contractor must take relevant responsibility.

5) Relevant information for party entering into agreement, which includes name of company, GUI number, address, telephone, name of person in charge and identity numbers.

6) Date of entering into agreement.

\section{Registration Card for Construction Project}

Content of registration card for construction project normally includes work details, deadline for required project, date of notification for commencement of project, number of working days, number of rain days, and number of days for project suspension, total number of working days, company signature and remarks.

\section{E. Content of Construction Project Record}

Content of construction project record normally includes date, items inspected, items improved \& comment, signature of inspector, company signature and remarks.

\section{Structure of Contract Management System}

This contract system would contain clicked option for project items, information input, message display and pulled option:

1) Clicked option for project items.

2) Information input.

3) Message display.

4) System information.

\section{A. Clicked option for Project Items}

This section contains the following 13 major categories with 160 detail items in total. Fig. 4 showed the classification of the project items.
TABLE 1.

ASSUMPTION WORKS

\begin{tabular}{|l|l|l|l|}
\hline $\begin{array}{l}\text { Dismantle old } \\
\text { house and } \\
\text { land } \\
\text { preparation }\end{array}$ & Setting out & $\begin{array}{l}\text { Bamboo } \\
\text { scaffolding }\end{array}$ & $\begin{array}{l}\text { Type A } \\
\text { fencing }\end{array}$ \\
\hline $\begin{array}{l}\text { Temporary } \\
\text { external water } \\
\text { \& electricity }\end{array}$ & $\begin{array}{l}\text { Iron } \\
\text { Scaffolding }\end{array}$ & $\begin{array}{l}\text { Composite } \\
\text { housing }\end{array}$ & Tower crane \\
\hline Working lift & & & \\
\hline
\end{tabular}

TABLE 2.

UNDERGROUND ESTIMATION

\begin{tabular}{|l|l|l|l|}
\hline $\begin{array}{l}\text { Earthwork for } \\
\text { independent } \\
\text { house }\end{array}$ & $\begin{array}{l}\text { Steel rail } \\
\text { piling }\end{array}$ & $\begin{array}{l}\text { Steel panel } \\
\text { piling }\end{array}$ & $\begin{array}{l}\text { Retaining } \\
\text { column }\end{array}$ \\
\hline $\begin{array}{l}\text { Retaining } \\
\text { work with } \\
\text { prepack piles }\end{array}$ & $\begin{array}{l}\text { Reverse } \\
\text { circulation } \\
\text { piling }\end{array}$ & $\begin{array}{l}\text { Water } \\
\text { stopping } \\
\text { piling with } \\
\text { high pressure } \\
\text { ejection }\end{array}$ & Sand piling \\
\hline $\begin{array}{l}\text { Safety support } \\
\text { with gravel } \\
\text { layer }\end{array}$ & $\begin{array}{l}\text { Excavation } \\
\text { for basement }\end{array}$ & $\begin{array}{l}\text { Excavation on } \\
\text { well points }\end{array}$ & $\begin{array}{l}\text { Water buffer } \\
\text { with gravel } \\
\text { layer }\end{array}$ \\
\hline $\begin{array}{l}\text { Safety support } \\
\text { with soft soil } \\
\text { layer }\end{array}$ & wiaphragm & $\begin{array}{l}\text { Water buffer } \\
\text { for soft soil } \\
\text { layer }\end{array}$ & $\begin{array}{l}\text { Ground } \\
\text { anchoring } \\
\text { with } \\
\text { pre-stressed } \\
\text { steel chain }\end{array}$ \\
\hline $\begin{array}{l}\text { Backfilling } \\
\text { for horizontal } \\
\text { retaining wall }\end{array}$ & $\begin{array}{l}\text { Working } \\
\text { catwalk }\end{array}$ & $\begin{array}{l}\text { Backfilling } \\
\text { with graded } \\
\text { aggregate }\end{array}$ & \\
\hline
\end{tabular}

TABLE 3

STRUCTURAL WORK

\begin{tabular}{|l|l|l|l|}
\hline Tieing rebar & Planting rebar & $\begin{array}{l}\text { Press } \\
\text { connection } \\
\text { with gas }\end{array}$ & $\begin{array}{l}\text { Rebar } \\
\text { connector }\end{array}$ \\
\hline $\begin{array}{l}\text { Spot weld } \\
\text { wire-mesh }\end{array}$ & Formwork & Concreting & Pre-casting \\
\hline Hollow floor & & & \\
\hline
\end{tabular}

TABLE 4

SUPERSTRUCTURE

\begin{tabular}{|l|l|l|l|}
\hline $\begin{array}{l}\text { Overall } \\
\text { plaster }\end{array}$ & Floor plaster & Floor tiling & Floor grinding \\
\hline Floor plaster & $\begin{array}{l}\text { Abrasion } \\
\text { resistant } \\
\text { flooring }\end{array}$ & $\begin{array}{l}\text { Cement work } \\
\text { for } \\
\text { independent } \\
\text { house }\end{array}$ & Brick laying \\
\hline $\begin{array}{l}\text { Laying hollow } \\
\text { bricks }\end{array}$ & $\begin{array}{l}\text { Laying ALC } \\
\text { bricks }\end{array}$ & Stone washing & $\begin{array}{l}\text { Internal wall } \\
\text { plastering }\end{array}$ \\
\hline $\begin{array}{l}\text { External wall } \\
\text { plastering }\end{array}$ & $\begin{array}{l}\text { Internal wall } \\
\text { tiling }\end{array}$ & $\begin{array}{l}\text { External wall } \\
\text { tiling }\end{array}$ & $\begin{array}{l}\text { Stone } \\
\text { grinding for } \\
\text { stairs }\end{array}$ \\
\hline $\begin{array}{l}\text { Partitioning } \\
\text { with wire } \\
\text { mesh, cement } \\
\text { \& mortar }\end{array}$ & Stone cutting & $\begin{array}{l}\text { Stone } \\
\text { brushing }\end{array}$ & \\
\hline
\end{tabular}

TABLE 5

INTERIOR DECORATION

\begin{tabular}{|l|l|l|l|}
\hline $\begin{array}{l}\text { PVC floor } \\
\text { bricks }\end{array}$ & $\begin{array}{l}\text { Cornice } \\
\text { flooring }\end{array}$ & $\begin{array}{l}\text { Wooden } \\
\text { flooring }\end{array}$ & $\begin{array}{l}\text { High platform } \\
\text { access } \\
\text { flooring }\end{array}$ \\
\hline $\begin{array}{l}\text { Wooden } \\
\text { kickers }\end{array}$ & $\begin{array}{l}\text { Stone material } \\
\text { for internal } \\
\text { wall }\end{array}$ & $\begin{array}{l}\text { Stone material } \\
\text { for floor }\end{array}$ & PVC kickers \\
\hline
\end{tabular}




\begin{tabular}{|l|l|l|l|}
\hline $\begin{array}{l}\text { Partition with } \\
\text { gypsum board }\end{array}$ & $\begin{array}{l}\text { Japanese style } \\
\text { partition }\end{array}$ & ALC panels & $\begin{array}{l}\text { Partition with } \\
\text { cement fiber } \\
\text { panel }\end{array}$ \\
\hline $\begin{array}{l}\text { Partition with } \\
\text { painted fire } \\
\text { proof steel } \\
\text { panel }\end{array}$ & $\begin{array}{l}\text { Wallpaper on } \\
\text { walls }\end{array}$ & PVC ceiling & $\begin{array}{l}\text { Aluminum } \\
\text { ceiling }\end{array}$ \\
$\begin{array}{l}\text { Mineral fiber } \\
\text { ceiling with } \\
\text { hidden frame }\end{array}$ & PVC painting & $\begin{array}{l}\text { Water-based } \\
\text { painting }\end{array}$ & $\begin{array}{l}\text { Wooden oil } \\
\text { paint }\end{array}$ \\
\hline
\end{tabular}

TABLE 6

EXTERIOR DECORATION

\begin{tabular}{|l|l|l|l|}
\hline $\begin{array}{l}\text { Metal } \\
\text { decoration on } \\
\text { external walls }\end{array}$ & $\begin{array}{l}\text { Dry } \\
\text { attachment } \\
\text { with stone } \\
\text { material }\end{array}$ & $\begin{array}{l}\text { Magnetic } \\
\text { paint spraying }\end{array}$ & $\begin{array}{l}\text { Wet } \\
\text { attachment } \\
\text { with stone } \\
\text { material }\end{array}$ \\
\hline $\begin{array}{l}\text { Working } \\
\text { doors with } \\
\text { wall column } \\
\text { \& enamel } \\
\text { board }\end{array}$ & GRC boards & Bottle fencing & $\begin{array}{l}\text { Roman } \\
\text { columns }\end{array}$ \\
\hline $\begin{array}{l}\text { Working } \\
\text { doors with } \\
\text { door column } \\
\text { \& enamel } \\
\text { board }\end{array}$ & $\begin{array}{l}\text { Oil paint on } \\
\text { external walls }\end{array}$ & $\begin{array}{l}\text { Painting on } \\
\text { steels }\end{array}$ & \\
\hline
\end{tabular}

TABLE 7

DOOR \& WINDOW

\begin{tabular}{|l|l|l|l|}
\hline Wooden door & $\begin{array}{l}\text { Aluminum } \\
\text { door \& } \\
\text { window }\end{array}$ & $\begin{array}{l}\text { Plastic steel } \\
\text { door \& } \\
\text { window }\end{array}$ & $\begin{array}{l}\text { Plastic steel } \\
\text { door for } \\
\text { toilets }\end{array}$ \\
\hline $\begin{array}{l}\text { Stainless door } \\
\text { \& window }\end{array}$ & $\begin{array}{l}\text { Vulcanized } \\
\text { copper }\end{array}$ & Painted doors & Entrance door \\
\hline $\begin{array}{l}\text { Automatic } \\
\text { door }\end{array}$ & $\begin{array}{l}\text { Steel rolling } \\
\text { doors }\end{array}$ & $\begin{array}{l}\text { Glass \& } \\
\text { mirror }\end{array}$ & $\begin{array}{l}\text { Gap sealing } \\
\text { for aluminum } \\
\text { door \& } \\
\text { window }\end{array}$ \\
\hline
\end{tabular}

TABLE 8

KITCHEN, TOLLET \& BATH FACILITY

\begin{tabular}{|l|l|l|l|}
\hline $\begin{array}{l}\text { Toilet \& bath } \\
\text { equipment }\end{array}$ & $\begin{array}{l}\text { Kitchen } \\
\text { equipment }\end{array}$ & & \\
\hline
\end{tabular}

Table 9

E \& $\mathrm{M}$ works

\begin{tabular}{|l|l|l|l|}
\hline E \& M & $\begin{array}{l}\text { Fire } \\
\text { prevention }\end{array}$ & Monitoring & $\begin{array}{l}\text { Weak } \\
\text { electrical } \\
\text { works }\end{array}$ \\
\hline $\begin{array}{l}\text { Hydraulic } \\
\text { stopping } \\
\text { equipment }\end{array}$ & Lift & $\begin{array}{l}\text { Emergency } \\
\text { generator }\end{array}$ & Intercom \\
\hline $\begin{array}{l}\text { Chain } \\
\text { stopping } \\
\text { equipment }\end{array}$ & & & \\
\hline
\end{tabular}

TABLE 10

CLEANING

\begin{tabular}{|l|l|l|l|}
\hline Stone work & $\begin{array}{l}\text { Paper } \\
\text { removing }\end{array}$ & Cleaning & $\begin{array}{l}\text { Blocking } \\
\text { water channel }\end{array}$ \\
\hline $\begin{array}{l}\text { Interior debris } \\
\text { cleaning }\end{array}$ & $\begin{array}{l}\text { Handing over } \\
\text { cleaning }\end{array}$ & $\begin{array}{l}\text { Waste } \\
\text { disposal }\end{array}$ & \\
\hline
\end{tabular}

TABLE 11

LANDSCAPING

\begin{tabular}{|l|l|l|l|}
\hline Landscaping & $\begin{array}{l}\text { Pavement } \\
\text { bricks }\end{array}$ & $\begin{array}{l}\text { Grass planting } \\
\text { bricks }\end{array}$ & \\
\hline
\end{tabular}

TABLE 12

MisCELLANEOUS

\begin{tabular}{|c|c|c|c|}
\hline $\begin{array}{l}\text { Roof water } \\
\text { proofing PU }\end{array}$ & $\begin{array}{l}\text { Roof } \\
\text { insulation }\end{array}$ & $\begin{array}{l}\text { Roof } \\
\text { insulating } \\
\text { bricks }\end{array}$ & $\begin{array}{l}\text { Cultural roof } \\
\text { tile }\end{array}$ \\
\hline $\begin{array}{l}\text { Filling water } \\
\text { proofing } \\
\text { material on } \\
\text { wall surfaces }\end{array}$ & $\begin{array}{l}\text { Stainless mail } \\
\text { box }\end{array}$ & Resin roof tile & $\begin{array}{l}\text { Anti-slip } \\
\text { bricks on } \\
\text { driveway }\end{array}$ \\
\hline $\begin{array}{l}\text { Abrasion-resis } \\
\text { tant \& } \\
\text { anti-slip } \\
\text { works on } \\
\text { driveway } \\
\end{array}$ & Parking lots & $\begin{array}{l}\text { Epoxy resin } \\
\text { works on } \\
\text { driveway }\end{array}$ & Silicon works \\
\hline $\begin{array}{l}\text { Gap filling on } \\
\text { pre-cast } \\
\text { external panel }\end{array}$ & $\begin{array}{l}\text { Water } \\
\text { proofing \& } \\
\text { plastering } \\
\end{array}$ & $\begin{array}{l}\text { Metal roof } \\
\text { tiles }\end{array}$ & \begin{tabular}{|l} 
Leaking \\
stoppage at \\
basement \\
\end{tabular} \\
\hline $\begin{array}{l}\text { Color steel } \\
\text { panel on roof }\end{array}$ & $\begin{array}{l}\text { Curtain } \\
\text { walling }\end{array}$ & $\begin{array}{l}\text { Aluminum } \\
\text { frames for } \\
\text { curtain } \\
\text { walling } \\
\end{array}$ & $\begin{array}{l}\text { Glazing for } \\
\text { curtain walling }\end{array}$ \\
\hline $\begin{array}{l}\text { Wooden } \\
\text { partition for } \\
\text { toilets }\end{array}$ & Elm hand rail & $\begin{array}{l}\text { Community } \\
\text { entrance gate }\end{array}$ & $\begin{array}{l}\text { Stainless steel } \\
\text { fence }\end{array}$ \\
\hline $\begin{array}{l}\text { Pre-cast septic } \\
\text { tank }\end{array}$ & Steel work & $\begin{array}{l}\text { Fire-resistant } \\
\text { coating }\end{array}$ & Expansion gap \\
\hline $\begin{array}{l}\text { Site installed } \\
\text { septic tank }\end{array}$ & $\begin{array}{l}\text { Sky light } \\
\text { works }\end{array}$ & $\begin{array}{l}\text { Drainage } \\
\text { gutter }\end{array}$ & $\begin{array}{l}\text { Walling with } \\
100 \text {-year } \\
\text { bricks }\end{array}$ \\
\hline \begin{tabular}{|l|} 
Filling of \\
expansion gap \\
on floor
\end{tabular} & $\begin{array}{l}\text { Service } \\
\text { counter }\end{array}$ & AC works & \\
\hline
\end{tabular}

TABLE 13

MATERIAL

\begin{tabular}{|l|l|l|l|}
\hline Rebar & Concrete & Cement & River sand \\
\hline $\begin{array}{l}\text { Marble } \\
\text { doorsill }\end{array}$ & Red bricks & Tiles & $\begin{array}{l}\text { Water } \\
\text { proofing agent }\end{array}$ \\
\hline Adhesives & $\begin{array}{l}\text { Gap filling } \\
\text { agent }\end{array}$ & Steel cover & \\
\hline
\end{tabular}

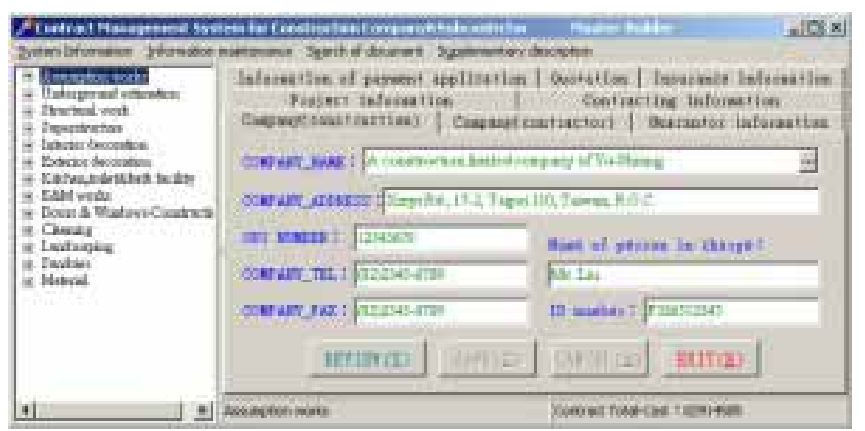

Fig 4 Classification of project items

\section{B. Data Input}

This area allows user to enter information required during setting of contract. This information includes:

1) Company information (construction company): Company name, address, GUI number, company telephone, fax, name of person in charge and identity number (shown in Fig. 5).

2) Company information (contractor): Company name, address, GUI number, company telephone, fax, name of person in charge and identity number. 
3) Guarantor information: Company name, address, GUI number, company telephone, fax, name of person in charge and identity number.

4) Project information: Name of project, location, scope of sub-contract, date of project commencement, primary court of jurisdiction (in the case of litigation, both the construction company and contractor agree to make a certain local court as the primary court of jurisdiction), counting of project duration (counted in calendar days or work days) and project period scheduled.

5) Contracting information: business tax (inclusive or extra addition), total contract price (automatically produced by the system), advance payment for the work, guaranteed period for the work, percentage of guarantee bond, percentage of payment stoppage for delayed work progress and date of contract.

6) Information of payment application: number of payment application per month (once or twice), date of payment application (stipulate the date of payment application), date of receiving payment (normally 5 to 15 days after payment application), amount of load allowed, usage, amount allowed for post dated, amount allowed for cash, rate of payment reserved (percentage), time of releasing payment reserved and things to note on payment release.

7) Quotation: this includes code editing, name, unit, quantity, unit rate and sub total for each detail item contracted; as well as total contract price (automatic summing by the system).

8) Insurance information: this includes status of using insurance information (optional), name of insurance company, amount paid for body injury (death), amount paid for medication and premium shared by the sub-contractor.

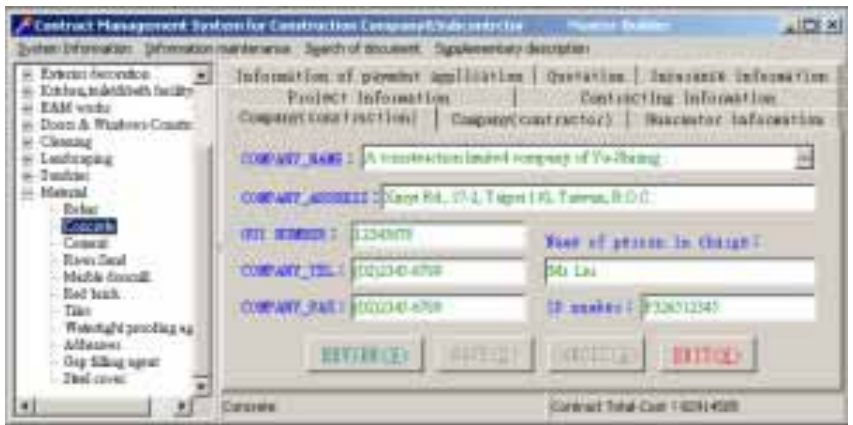

Fig 5 Input of company information

\section{Message Display}

This part is divided into display of selected project item and total contract price (as shown in Fig. 6).

\section{System Information}

The information in this area includes setting of system, maintenance of information (as shown in Fig. 7), search for document and supplementary description. The function of each option list is described as follows:

1) Setting of system a. Save document created;

b. Setting user: this describes level of authority for each user.

c. Maintenance of password: change password for the user.

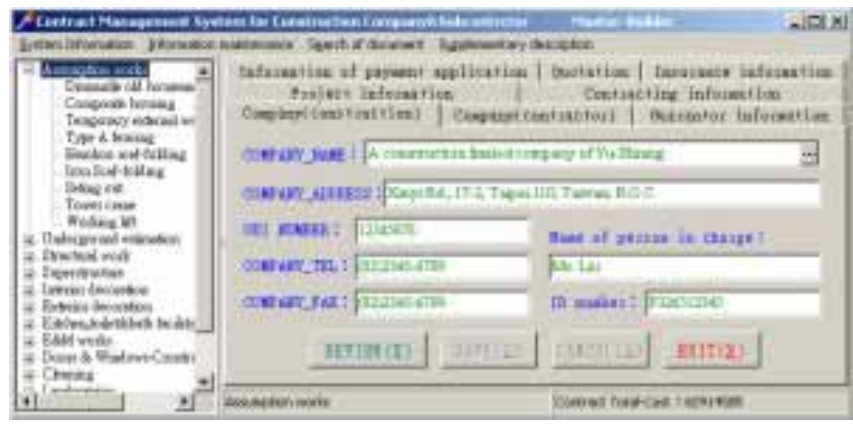

Fig 6 Display of total contract price

2) Information maintenance

a. Maintenance of company information: Enter or modify information of construction company.

b. Maintenance of contractor information: Enter or modify information of contractor.

c. Maintenance of guarantor information: Enter or modify information of guarantor.

d. Maintenance of project information: Enter or modify name and address of project.

e. Maintenance of court information: Enter name of court.

3) Search of document

Search for created contract: These searches for company name, project name, contracting items, date of work commencement and date of contract production.

4) Supplementary description

User's manual: description of application is attached, which divides into 8 chapters and records method of application for option list of each item in detail.

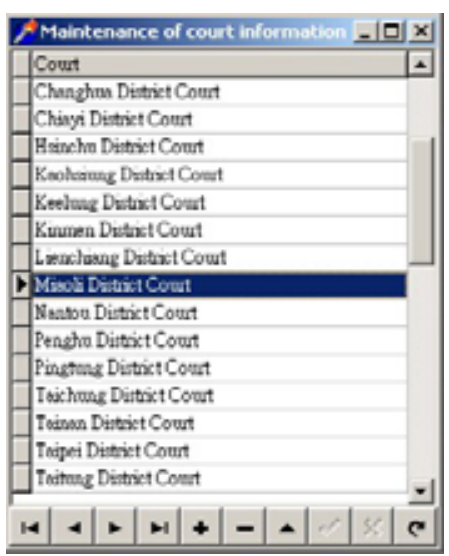

Fig 7 Maintenance of court information

The main function of this system is to help construction company with setting of agreement for sub-contract works. When user clicks on project item to be contracted and enters relevant project information, the system will automatically 
produce a copy of construction agreement, which clearly lists relevant things to note for each project item in an edited and complete structure.

\section{CONCLUSIONS \& SUgGestions}

\section{A. Conclusion}

This program compiled management of documentation and project regulations between sub-contractors and building material suppliers in project management of domestic construction industry. While operating for complicated constriction project in particular, the construction company would transfer various professional works to sub-contractors. With functions of prompt reference, editing and modifying of this system, a suitable agreement can be customized to each different type of cooperative team, which compile relations of rights and duties between all project teams, as well as acceleration in promotion of an environment and mechanism managed by the company. From this research, we could provide a fair and effective management system. This would help the domestic construction industry to perform well contract management of setting of work regulation, which would prevent disputes caused from incomplete setting of contract between construction company and sub-contractors. Furthermore, this would also improve capability and competitive advantage of construction industry, which would create more profit for the domestic construction industry. The functions achieved were the following:

1) Arrangement of work regulation: At present, Yushian Construction has completed work regulation for 13 major items and 160 types of work.

2) Establishment of contract structure: This research expected to divide subcontracting of normal construction company into the following major items:
a. Construction contract.
b. Construction description.
c. Things to note for construction project.
d. Requirements of construction project.
e. Construction quotation.
f. Guarantee of contract.
g. Worker's insurance agreement.
h. Agreement of project safety \& health.
i. Stamp card for company receipt of payment
j. Record of construction project.
k. Registration card of construction project.

3) Interface development of user's program. The expected input information interface to be developed in this research includes:
a. Company information (construction company).
b. Company name, address, name of person in charge, GUI number and telephone.
c. Company information (contractor).

d. Company name, address, name of person in charge, GUI number and telephone.

e. Guarantor information

f. Company name, address, name of person in charge, GUI number and telephone.

g. Project information

h. Name of project, location, date of project commencement, date of completion and primary court of jurisdiction.

i. Contracting information

j. Name, work scope, quantity \& rate of each detail item, total contract price, period of guarantee and shop drawing of items contracted with the contractor.

k. Information of payment application

l. Date of payment application, time of payment, amount allowed for each payment release, usance of payment release, advance payment and payment reserved.

m. Quotation

n. Unit, quantity, rate, sub-total and total price of each described item included in the contract.

o. Insurance information

p. This includes name of insurance company, amount paid for body injury, amount paid for medication and premium shared by the sub-contractor.

\section{B. Contribution}

From main function of this system and for helping the construction company to deal with setting of sub contract project, the system could automatically create a copy of construction contract after the user clicks on contracted project items and enters information of relevant project. This contract would clearly list relevant things to note in an edited complete structure. The expected contribution of contract management system developed from this research includes the following;

1) For the industry

a. Provision of contract management software with full functions for domestic construction industry.

b. In this system, relevant information such as construction company and others only needed to be entered once, where automatic filling would be made at each relevant location in the contract for avoidance of repetitive input.

c. This system regulated rights and duties for both construction company and contractor very clearly, which gave both parties a basis to be followed together for reduction of possible creation of future dispute.

d. Supervision was made according to key points instructed in the system. The construction personnel could then effectively carry out the supervision and management, which allows comprehensive control on newcomers or new project items for effective achievement of mission for the company.

e. The system stipulated penalties on delayed project schedule and project not in accordance with contract requirements; the construction personnel only had to execute according to the contract requirement.

f. Things to note for each project item would be 
pre-considered in the system. This would ensure completeness of the contract to significant degree, thus important clauses would not be omitted during busy activity, as well as causing difficulty for future execution and possible losses to the company.

2) For national development

a. This program would enhance competitiveness of domestic construction industry, which would reduce contract management time of traditional construction industry, increase accuracy of contract management for the company and further lower costs on operational management for improvement of competitiveness.

b. The current profit for domestic construction industry was very low, thus this research would help for prompt control of construction cost, increase work efficiency and put the goal from government to enhance competitiveness of industry into practice.

c. The system mentioned in this program would be helpful to the government on promotion of making e-construction industry.

3) For other application

Since the applicability of IT industry itself was quite extensive, where the application on other industry and renewal of module were not difficult after appropriate modular process of contract management in construction industry, this system may act as reference and basis of the whole e-industry and automatic management.

\section{ACKNOWLEDGEMENT}

I would like to take this opportunity to show my appreciation to National Science Council, Executive Yuan, for its support of the study. Project No.: NSC 92-2622-E-216-021-CC3.

\section{REFERENCE}

[1] Public construction work criterion editing \& information integration center, Public construction commission, Executive Yuan.

[2] User's manual for construction contract and operation of document management system for Primavera Expedition Suite

[3] Tianlong Huang, "Study of integration and analysis procurement contract performance management for national defense in Taiwan”, Masters Thesis, Institute of decision science, Nation defense university, 2000.

[4] Meilin Kuo, "Study on key items of public construction contract", Masters Thesis, Institute of construction engineering, Nation Taiwan University of Science and Technology, 2000.

[5] Yiting Chen, "Study on sharing relevant information of construction contract”, Masters Thesis, Institute of civil engineering, National Taiwan University, 1998.

[6] Huichu Tsai, "Discussion on construction contract management and drafting of management criterion”, Masters Thesis, Department of architecture and urban planning, Chung Hua University, 1997.

[7] Tsiyu Lin, "Setting of public construction contract and duty of authority for tender invitation”, Masters Thesis, Institute of law, Nation Taiwan University, 2001.

[8] Guofeng Lin, "Study of management for shop drawing operation for construction site”, Masters Thesis, Department of architecture, National Cheng Kung University, 1998. 